\title{
THE PRODUCTION OF ACETONE- BUTANOL-ETHANOL FROM OIL PALM WASTES BY Clostridium acetobutyricum AND UTILISATION OF THE WASTEWATER FOR POLYHYDROXYBUTYRATE PRODUCTION
}

\author{
KANOKPHORN SANGKHARAK*; TEWAN YUNU*; NISA PAICHID* and POONSUK PRASERTSAN**
}

\begin{abstract}
Oil palm wastes including palm oil mill effluent (POME), empty fruit bunch (EFB), palm pressed fibre (PPF) and palm kernel shell (PKS) were collected and utilised as substrate for acetone-butanolethanol ( $A B E)$ production. Each waste was pre-treated before use. POME was centrifuged to obtain the supernatant. EFB, PPF and PKS were pre-treated by steam explosion and hydrolysed by cellulase from Aspergillus niger. The cultivation of Clostridium acetobutyricum under $180 \mathrm{ml}$ of diluted POME supplemented with $10 \mathrm{~g}$ litre ${ }^{-1}$ of pre-treated EFB gave the maximum $A B E$ and total acids at $3.8 \mathrm{~g}$ litre $^{-1}$ and $2.0 \mathrm{~g} \mathrm{litre}^{-1}$, respectively. The ABE production was then recovered by distillation. The wastewater after distillation was collect and characterised. Wastewater contained organic acid profiles such as acetic acid, particularly propionic and butyric acid in the amount of 0.1-1.0 $\mathrm{g}$ litre ${ }^{-1}$. Acetic and butyric present in wastewater can possibly be used for polyhydroxybutyrate (PHB) production. Therefore, the wastewater was utilised as substrate for PHB production by Cupriavidus necator. The maximum PHB (48.4\% of dry cell weight, DCW) was obtained after $60 \mathrm{hr}$ of cultivation. The polymer was identified by gas chromatography to be PHB when compared to commercially available product.
\end{abstract}

Keywords: acetone, butanol, ethanol, palm oil mill effluent, palm pressed fibre, polyhydroxybutyrate.

Date received: 14 June 2015; Sent for revision: 28 July 2015; Received in final form: 17 December 2015; Accepted: 19 January 2016.

\section{INTRODUCTION}

Palm oil is one of the most important agricultural products for tropical countries, including Thailand. Palm oil occupies $70 \%$ of the Thai vegetable oil market and is estimated to be worth 1.5 billion USD

\footnotetext{
* Department of Chemistry, Faculty of Science, Thaksin University, 93210 Phatthalung, Thailand. E-mail: skanokphorn@yahoo.com

** Department of Industrial Biotechnology, Faculty of Agro-industry, Prince of Songkla University, 90112 Songkhla, Thailand.
}

per annum with an average growth rate of $15 \%$ during the last decade (Chavalparit et al., 2006). In 2003 there were 25 wet-process crude palm oil factories in Thailand, producing about 0.7 million tonnes of crude palm oil from 4 million tonnes of fresh fruit bunches (FFB). Therefore, the wastes from palm oil factories increase rapidly with the increase of palm oil production. Large amounts of solid and liquid wastes are generated by the milling process and plantation activities. The average values of waste generation rate per tonne of FFB from palm oil mill industries in Thailand were $9 \times 10^{5} \mathrm{t} \mathrm{yr}^{-1}$ of EFB, $6 \times 10^{5}$ 
$\mathrm{t} \mathrm{yr}^{-1}$ of fibre and $2 \times 10^{5} \mathrm{t} \mathrm{yr}^{-1}$ of shells (Chavalparit et al., 2006). Moreover, it has been estimated that $1 \mathrm{t}$ of crude palm oil production requires 5-7.5 $\mathrm{t}$ of water in which about $50 \%$ ends up as palm oil mill effluent (POME). Normally, fibres and shells are utilised as fuel to generate steam and electricity in the palm processing mill itself. However, much is also wasted by dumping in areas adjacent to the mill, or utilised as fertiliser in the palm oil plantation. In recent years, growing attention has been paid to the production of fine chemicals from oil palm biomass. Fortunately, oil palm biomass shows potential as an industrial fermentation substrate, which could produce valuable chemical products (Sumathi et al., 2008).

Solvent-producing clostridia could produce acetone, butanol, and ethanol (ABE) from several biomasses such as palm oil waste (Jones and Wood, 1986). Acetic acid and butyric acid are produced first at an early stage of fermentation by Clostridia sp., known as the acidogenesis phase, before the cells enter solventogenesis phase to produce ABE. Hydrogen and carbon dioxide are also released as by-products throughout the glycolysis process by this microorganism (Mitchell, 1998). In addition, Clostridia have the ability to utilise hexose and pentose, sugar monomers released from woody materials (Singh, 1995; Ibrahim et al., 2012). There are many species that have been studied for acids and ABE production. Clostridrium acetobutylicum and $C$. beijerinckii are the main species for ABE fermentation that are normally employed for butanol production (Vandak et al., 1997; Liu and Yang, 2006; Lee et al., 2008). Several wastes from palm oil mill such as empty fruit bunch (EFB), fibre, separator sludge and POME were able to support production of ABE by Clostridia sp. C. saccharoperbutylacetonicum N1-4 without any need for mineral supplements. Besides that, enzymatic hydrolysis by cellulose prior to fermentation was found to increase the yield of butanol by $75 \%$ (from $2.47 \mathrm{~g} \mathrm{litre}^{-1}$ to $4.37 \mathrm{~g}$ litre $^{-1}$ ) (Mun et al., 1995). Clostridium butyricum EB6 was also employed for $\mathrm{ABE}$ fermentation using fermentable sugar derived from treated oil palm empty fruit bunch (OPEFB). A highest amount of ABE (3.5 g g litre $\left.^{-1}\right)$ was produced in a fermentation using treated OPEFB at pH 6.0 (Ibrahim et al., 2012). Clostridium acetobutylicum NCIMB 13357 grown in 90\% sediment POME with initial $\mathrm{pH} 5.8$ produced highest total ABE (4.0 g litre $^{-1}$ ) (Kalil et al., 2003). However, the utilisation of co-substrates from palm wastes to increase ABE production has only little information. In addition, the re-utilise of wastewater after ABE production have never been reported so far. In this study, wastewater from ABE production was utilised for polyhydroxybutyrate (PHB) production. $\mathrm{PHB}$, a member of the polyhydroxyalkanoate (PHA) family, produced by various microorganisms apparently in response to conditions of physiological stress. PHB are suitable for applications in several areas such as household, industrial, pharmaceutical, medical and other application. Therefore, this research aim to investigate the possibility of $\mathrm{ABE}$ production from various oil palm wastes including POME, EFB, PPF and PKS by C. acetobutylicum. The utilisation of single and co-substrates were also determined. Afterward, the $A B E$ was recovered and the wastewater after distillation was collected and utilised as a substrate for PHB production by Cupriavidus necator.

\section{MATERIALS AND METHODS}

\section{Microorganism and Inoculum Preparation}

Clostridium acetobutylicum TISTR1462 and Cupriavidus necator TISTR1335 were purchased from the Thai Institute of Scientific and Technological Research (Thailand) and utilised for ABE and PHA production, respectively.

The stock culture of $C$. acetobutylicum was maintained in the form of a spore suspension in $25 \%$ glycerol and frozen at $-20^{\circ} \mathrm{C}$. The inoculum was prepared by transferring the suspension of spores $(1 \mathrm{ml})$ to $10 \mathrm{ml}$ of $15 \%$ potato-glucose (PG) medium

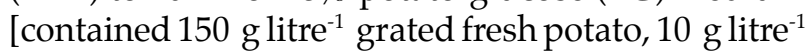
glucose, $0.5 \mathrm{~g}$ litre ${ }^{-1}\left(\mathrm{NH}_{4}\right)_{2} \mathrm{SO}_{4}$ and $3 \mathrm{~g} \mathrm{litre}^{-1} \mathrm{CaCO}_{3}$ ] and heat shock for $1 \mathrm{~min}$ in boiling water, followed by cooling in iced water and incubation under anaerobic conditions for one to two days at $30^{\circ} \mathrm{C}$ (Al-Shorgani et al., 2012). The colony morphology and gram-staining behaviour of the inoculums was checked to ensure that the culture was pure. This initial culture was then transferred to tryptoneyeast extract-acetate medium (TYA medium) and incubated for 15-18 hr and used as the inoculum. TYA medium was used for the pre-culture consisted of $20 \mathrm{~g}$ litre $^{-1}$ glucose, $2 \mathrm{~g}_{\text {litre }}{ }^{-1}$ yeast extract, $6 \mathrm{~g}$ litre $^{-1}$ tryptone, $3 \mathrm{~g}$ litre $^{-1} \mathrm{CH}_{3} \mathrm{COONH}_{4} 0.3 \mathrm{~g}$ litre $^{-1}$ $\mathrm{MgSO}_{4} \cdot 7 \mathrm{H}_{2} \mathrm{O}, 0.5$ g litre $^{-1} \quad \mathrm{KH}_{2} \mathrm{PO}_{4}$ and $10 \mathrm{mg}$ litre $^{-1}$ $\mathrm{FeSO}_{4} \cdot 7 \mathrm{H}_{2} \mathrm{O}$. The medium was sterilised at $121^{\circ} \mathrm{C}$ for $15 \mathrm{~min}$.

Cupriavidus necator was utilised for the production of PHA. Starter culture of C. necator TISTR1335 was prepared by cultivating aerobically with shaking $(150 \mathrm{rpm})$ in medium consisted of $(\mathrm{g}$ litre $^{-1}$ ): 30 glycerol, 30 casein peptone, $1 \mathrm{KH}_{2} \mathrm{PO}_{4^{\prime}} 0.01$ $\mathrm{CaCl}_{2}$ pH 6.8, supplemented with $5 \mathrm{ml}$ of the trace elements solution. The culture was cultivated in medium at $37^{\circ} \mathrm{C}$ for $24 \mathrm{hr}$. Afterward aliquots were removed to determine cell growth by measurement of optical density at $660 \mathrm{~nm}$.

\section{The Preparation of Oil Palm Wastes}

Oil palm wastes including POME, EFB, PPF and PKS were kindly received from the Krabi Oil Palm Farmers Cooperatives Federation Limited (Krabi, 
Thailand). Each waste was pre-treated before use. POME was centrifuged. Only supernatants were collected and diluted with distilled water in the optimal ratio at 25\% dilution (Sangkharak and Prasertsan, 2012). The diluted POME was kept at $-4^{\circ} \mathrm{C}$ to prevent the microbial degradation.

EFB, PPF and PKS were cut into small piece and sun dried for two days, then stored in a plastic bag and kept at room temperature until used. Thereafter, EFB, PPF and PKS were soaked overnight in a commercial dish washing detergent before they were washed with tap water to remove oil and dust. Then, the washed materials were dried in an oven at $60^{\circ} \mathrm{C}$ for $24 \mathrm{hr}$ (Ibrahim et al., 2015). Each material of $10 \mathrm{~g}$ was soaked again in distilled water for $4 \mathrm{hr}$ followed by the steam explosion pre-treatment. The steam explosion experiments were performed in laboratory scale equipment consisting of a modified steel autoclave with a volume of 1.2 litres. All experiments were performed with saturated steam at 1.1 bar which corresponds to around $121^{\circ} \mathrm{C}$ in the steam explosion equipment for $60 \mathrm{~min}$.

\section{Hydrolysis of Oil Palm Wastes}

Cellulase from Aspergillus niger (Sigma Chemical Co., USA) was utilised. The cellulase stock was diluted in $0.1 \mathrm{M}$ of phosphate buffer, $\mathrm{pH} 5.5$ to give an initial $\beta$-glucosidase activity of $5.0 \mathrm{U} \mathrm{ml}^{-1}$ before it was filtered through $0.45 \mu \mathrm{m}$ of membrane filter using vacuum pump to remove the remaining debris from the cellulase solution (Ibrahim et al., 2015).

\section{Acetone-butanol-ethanol Fermentation}

Oil palm wastes were prepared and utilised for ABE fermentation as described in Figure 1. The ABE production was fermented in $250 \mathrm{ml}$ Erlenmeyer flasks seal with cellulose caps under different medium as described in Table 1. The medium were prepared according to the method of Parrer et al. (2000) by growth of C. acetobutylicum TISTR1462 in a two-stage chemostat with on-line solvent removal. In addition, $5 \mathrm{U} \mathrm{ml}^{-1}$ of cellulase was added to medium (treatment number 1-7) for the saccharification of pre-treated EFB, PPF and PKS into fermentable sugar. The $\mathrm{pH}$ of medium was adjusted to 7.0 by an addition of $0.2 \mathrm{M} \mathrm{NaOH}$ and $0.1 \mathrm{M} \mathrm{HCl}$ prior to sterilisation $\left(121^{\circ} \mathrm{C}\right.$ for $\left.15 \mathrm{~min}\right)$. Before inoculation, the medium was covered with nitrogen gas to maintain strict anaerobic condition. Thereafter, the process was initiated by inoculating $10 \mathrm{ml}$ of prepared inoculums (with the $\mathrm{OD}_{620}$ set at $1.0)$ into the medium. The cultivation was incubated at $37^{\circ} \mathrm{C}$ with an agitation speed of $150 \mathrm{rpm}$ for $144 \mathrm{hr}$ using a shaker incubator. A $2 \mathrm{ml}$ of the liquid sample from each fermentation bottle was withdrawn using a syringe and kept at $-20^{\circ} \mathrm{C}$ prior to sample analysis.

\section{The Production of Polyhydroxyalkanoate}

After $144 \mathrm{hr}$ of ABE fermentation and application of the solvent removal processes, the supernatant was recovered by centrifugation (5000 rpm, $10 \mathrm{~min}$ ) and utilised as substrate for PHB production. The broth was sterilised $\left(121^{\circ} \mathrm{C}, 15 \mathrm{~min}\right)$ without adjust of $\mathrm{pH}$ and any further preparation step.

The starter culture $(5 \%)$ of $C$. necator was added into the $200 \mathrm{ml}$ medium (supernatant after ABE recovery) without any supplemented nutrients and cultivated on a rotary shaker $(150 \mathrm{rpm})$ at $37^{\circ} \mathrm{C}$ for $96 \mathrm{hr}$. Samples were taken at the first $6 \mathrm{hr}$ and then every $12 \mathrm{hr}$ to measure for $\mathrm{pH}$, growth (OD $660 \mathrm{~nm}$ ), dry cell weight, the concentrations of PHB.

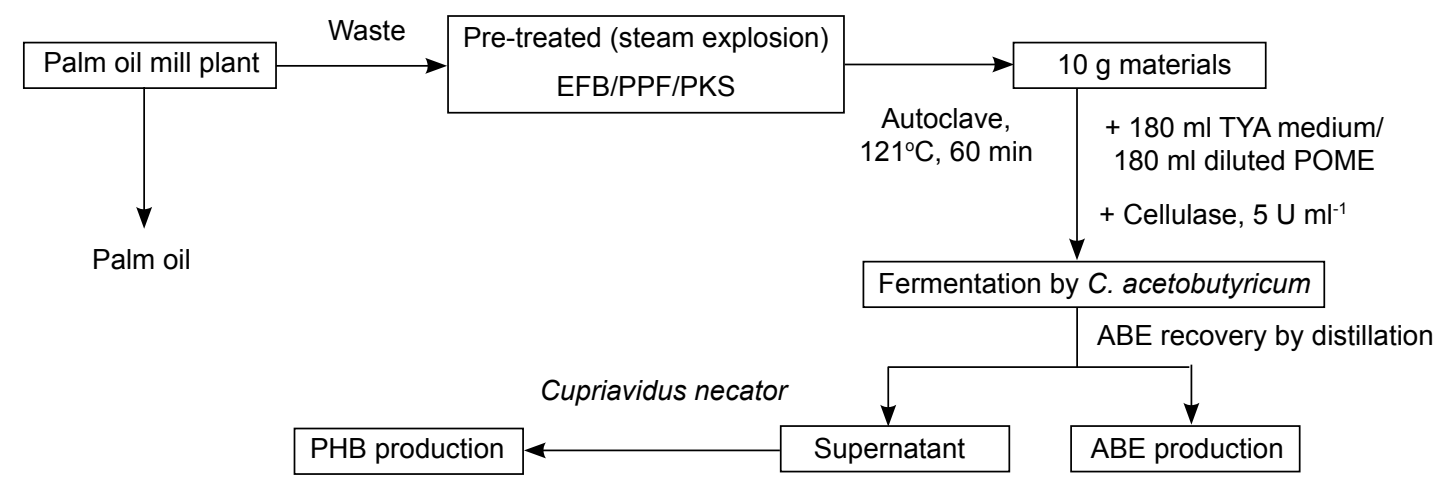

Note: PHB - polyhydroxybutyrate.

TYA - tryptone-yeast extract-acetate.

Figure 1. Experimental design for acetone-butanol-ethanol (ABE) fermentation using pre-treated empty fruit bunch (EFB), palm pressed fibre (PPF), palm kernel shell (PKS) and palm oil mill effluent (POME) as substrate. 
TABLE 1. THE PRODUCTION OF ACETONE-BUTANOL-ETHANOL UNDER DIFFERENT CULTIVATION MEDIUM AFTER 144 hr OF CULTIVATION

\begin{tabular}{|c|c|c|c|c|c|c|c|c|c|}
\hline $\begin{array}{l}\text { Conditions } \\
\text { number }\end{array}$ & Medium & $\begin{array}{l}\text { Acetone } \\
\left(\text { g litre }^{-1}\right)\end{array}$ & $\begin{array}{l}\text { Butanol } \\
\left(\text { g litre }^{-1}\right)\end{array}$ & $\begin{array}{l}\text { Ethanol } \\
\left(\text { g litre }^{-1}\right)\end{array}$ & $\begin{array}{c}\text { ABE } \\
\left(\text { g litre }^{-1}\right)\end{array}$ & $\begin{array}{c}\text { Yield } \\
\text { (g butanol/g } \\
\text { total sugar) }\end{array}$ & $\begin{array}{l}\text { Acetic } \\
\text { acid } \\
\left(\text { g litre }^{-1}\right)\end{array}$ & $\begin{array}{l}\text { Butyric } \\
\text { acid } \\
\left(\text { g litre }^{-1}\right)\end{array}$ & $\begin{array}{c}\text { Total } \\
\text { acids } \\
\left(\mathrm{g} \text { litre }^{-1}\right)\end{array}$ \\
\hline 1 & $\begin{array}{l}180 \mathrm{ml} \text { diluted } \\
\text { POME }\end{array}$ & 0.1 & 1.5 & 0.1 & 1.7 & 0.05 & 0.8 & 0.8 & 1.6 \\
\hline 2 & $\begin{array}{l}180 \mathrm{ml} \text { TYA } \\
\text { medium }+10 \mathrm{~g} \\
\text { pre-treated EFB }\end{array}$ & 0.1 & 3.9 & 0.1 & 4.1 & 0.08 & 0.9 & 1.1 & 2.0 \\
\hline 3 & $\begin{array}{l}180 \mathrm{ml} \text { TYA } \\
\text { medium }+10 \mathrm{~g} \\
\text { pre-treated PPF }\end{array}$ & 0.1 & 3.1 & 0.1 & 3.3 & 0.08 & 0.6 & 0.9 & 1.5 \\
\hline 4 & $\begin{array}{l}180 \mathrm{ml} \text { TYA } \\
\text { medium }+10 \mathrm{~g} \\
\text { pre-treated PKS }\end{array}$ & 0.1 & 1.5 & ND & 1.6 & 0.05 & 0.1 & 0.1 & 0.2 \\
\hline 5 & $\begin{array}{l}180 \mathrm{ml} \text { diluted } \\
\text { POME }+10 \mathrm{~g} \text { pre- } \\
\text { treated EFB }\end{array}$ & 0.1 & 3.5 & 0.2 & 3.8 & 0.10 & 0.8 & 1.2 & 2.0 \\
\hline 6 & $\begin{array}{l}180 \mathrm{ml} \text { diluted } \\
\text { POME }+10 \text { g pre- } \\
\text { treated PPF }\end{array}$ & 0.1 & 3.0 & 0.1 & 3.2 & 0.10 & 0.5 & 0.9 & 1.4 \\
\hline 7 & $\begin{array}{l}180 \mathrm{ml} \text { diluted } \\
\text { POME }+10 \mathrm{~g} \text { pre- } \\
\text { treated PKS }\end{array}$ & 0.1 & 1.0 & ND & 1.1 & 0.05 & 0.1 & 0.1 & 0.2 \\
\hline $\begin{array}{l}\text { Negative } \\
\text { control }\end{array}$ & $180 \mathrm{ml}$ TYA & 0.1 & 1.0 & ND & 1.1 & 0.03 & 0.8 & 0.9 & 1.7 \\
\hline $\begin{array}{l}\text { Positive } \\
\text { control }\end{array}$ & $\begin{array}{l}180 \mathrm{ml} \text { TYA }+40 \mathrm{~g} \\
\text { litre }^{-1} \text { glucose }\end{array}$ & 0.2 & 4.1 & 0.2 & 4.5 & 0.07 & 1.0 & 1.2 & 2.2 \\
\hline
\end{tabular}

Note: ND - not detectable. POME - palm oil mill effluent. ABE - acetone-butanol-ethanol. TYA - tryptone-yeast extract-acetate. EFB - empty fruit bunch. PPF - palm pressed fibre. PKS - palm kernel shell.

\section{Analytical Method}

The drawn samples from $\mathrm{ABE}$ fermentation were centrifuged at $10000 \mathrm{rpm}$ for $5 \mathrm{~min}$ to separate the liquid and the cells. The yield of butanol was calculated as the butanol produced divided by the total sugar utilised. The yield of products was expressed as gram butanol/gram total sugar. The productivity of $\mathrm{ABE}$ was calculated as $\mathrm{ABE}$ concentration $\left(\mathrm{g}\right.$ litre $^{-1}$ ) divided by fermentation time (hr). The liquid was used for the determination of $\mathrm{pH}$, reducing sugar, cellulase activity, solvent concentrations (ABE) and acid concentrations (acetic acid and butyric acid) while the pellets were used for the determination of cell concentrations. Changes of $\mathrm{pH}$ were measured using a $\mathrm{pH}$ meter. The concentrations of solvents and acids were determined using gas chromatography (GC) (Shimadzu, Japan) equipped with column BP20 and thermal ionisation detector (Ibrahim et al., 2012). The temperature of the detector and injector were maintained at $270^{\circ} \mathrm{C}$ and $230^{\circ} \mathrm{C}$, respectively. The cell concentration was determined based on the optical density (OD) analysis measured at $620 \mathrm{~nm}$ using spectrophotometer (GENESYS 20, Thermo
Scientific, United States) calibrated with dry cell weight (DCW) as a standard.

The cellulose and lignin amounts from oil palm wastes were estimated by the AOAC method (AOAC, 1990). The reducing sugar amounts were estimated by dinitrosalicylic acid (DNS) method (Miller, 1959) using a glucose standard calibration curve. Cellulase activity was determined by the method of Wood and Bhat (1988). One unit (U) of cellulase is defined as the amount of enzyme releases the 1 mole of glucose equivalent per min under the assay conditions.

POME was measured for $\mathrm{pH}$ and analysed for biological oxygen demand (BOD), chemical oxygen demand (COD), total solids, suspended solids, oil and grease as well as total nitrogen concentration (APHA, 1988). Volatile fatty acids (VFA) were identified by GC.

The polymer from C.necator was extracted and subjected to analysis by GC and Attenuated total reflectance-Fourier transform infrared spectroscopy (ATR-FTIR). The functional group of polymer was characterised ATR-FTIR. All IR spectra were recorded at a $2 \mathrm{~cm}^{-1}$ resolution, between 4000 and $400 \mathrm{~cm}^{-1}$ (Oliveira et al., 2007). 


\section{RESULTS AND DISCUSSION}

\section{Acetone-butanol-ethanol Production from Palm Wastes}

The cultivation was established under different medium as described in Table 1. In this study, $5 \mathrm{U}$ $\mathrm{ml}^{-1}$ of cellulase was added to medium due to C. acetobutylicum was not able to produce enough cellulase activity $\left(0.2 \mathrm{U} \mathrm{ml}^{-1}\right)$. The ABE production from each cultivation medium as presented in Table 1. The major components in the medium after enzyme hydrolysis are sugar and the organic acids. The quantity of initial sugar was range from 9.24-28.21 g litre ${ }^{-1}$ depending on the substrate. Oil palm waste contains glucose as its dominant sugar followed by sucrose, fructose and galactose (data not shown). The glucose has been observed to be the most favourable substrate for butanol production by C. acetobutylicum (Khamaiseh et al., 2014). The highest ABE production was obtained from experiment number 2 consisting $180 \mathrm{ml}$ TYA medium and $10 \mathrm{~g}$ litre $^{-1}$ pre-treated EFB which produced ABE up to $4.1 \mathrm{~g} \mathrm{litre}^{-1}$ (0.1 $\mathrm{g}_{\text {litre }}{ }^{-1}$ acetone, $3.9 \mathrm{~g} \mathrm{litre}^{-1}$ butanol and $0.1 \mathrm{~g}$ litre $^{-1}$ ethanol) and $2.0 \mathrm{~g}$ litre $^{-1}$ of total acids ( $0.9 \mathrm{~g}$ litre $^{-1}$ acetic acid and $1.1 \mathrm{~g}$ litre $^{-1}$ butyric acid $)$ correspond with yield of butanol at $0.08 \mathrm{~g}$ butanol $/ \mathrm{g}$ total sugar. However, the highest yield of butanol ( $0.10 \mathrm{~g}$ butanol/g total sugar) was produced at 180 $\mathrm{ml}$ diluted POME supplemented with $10 \mathrm{~g} \mathrm{litre}^{-1}$ pre-treated EFB with a ABE value as high as $3.8 \mathrm{~g}$ litre $^{-1}\left(0.1 \mathrm{~g}\right.$ litre $^{-1}$ acetone, $3.5 \mathrm{~g} \mathrm{litre}^{-1}$ butanol and $0.2 \mathrm{~g}$ litre $^{-1}$ ethanol) and $2.0 \mathrm{~g}$ litre $^{-1}$ of total acids (0.8 $\mathrm{g} \mathrm{litre}^{-1}$ acetic acid and $1.2 \mathrm{~g}$ litre $^{-1}$ butyric acid) (Table 1). Therefore, POME supplemented with pre-treated EFB is a good candidate for the ABE production. POME has great potential as a substrate for $\mathrm{ABE}$ fermentation because it contains a mixture of carbohydrates including starch, hemicellulose, sucrose and other carbohydrates that can be utilised by microorganisms (Al-shorgani et al., 2015). In addition, pre-treated EFB is a potential source of cellulose which can also serve as a promising raw material for the production of $\mathrm{ABE}$. Highest cellulose $(66.2 \%)$ was obtained from pre-treated EFB. The characterisation of EFB, PPF and PKS showed that EFB contained the highest cellulose (48.4\%) followed by PPF (32.2\%) while PKS had the lowest cellulose $(10.4 \%)$. After steam explosion treatment $\left(121^{\circ} \mathrm{C}, 60 \mathrm{~min}\right)$, the percentage of cellulose in EFB was significantly increased (Table 2). The use of the agro-based industrial wastes is one of the attractive strategies for economical ABE production. The utilisation of waste and/or waters, rich in organic pollutants, has a double benefit of reducing the pollutants while producing useful products. Another approach involves using raw substrates with negligible or no value (Makkar et al., 2011).

The ABE production of POME with addition of EFB was not significantly different from positive control. The positive control contain $180 \mathrm{ml}$ TYA medium with an addition of $40 \mathrm{~g}$ litre $^{-1}$ glucose yield $0.2 \mathrm{~g}$ litre $^{-1}$ acetone, $4.1 \mathrm{~g}$ litre $^{-1}$ butanol and $0.2 \mathrm{~g} \mathrm{litre}^{-1}$ ethanol and $2.2 \mathrm{~g} \mathrm{litre}^{-1}$ total acids at $144 \mathrm{hr}$ of cultivation. This happened due to the effect of improving the balance between the nutrients carbon and nitrogen. POME and pre-treated EFB were a suitable source for organic acids (acetic and butyric acid) and reducing sugar, respectively. POME used in this study was characterised. Low nitrogen content was observed in POME (850 ppm) and it was correlated with the presence of $150 \mathrm{ppm}$ of ammonium-nitrogen. The BOD was estimated to be around 20,000 ppm. POME was acidic ( $\mathrm{pH}$ 4.59). The organic acid profiles such as formic acid, acetic acid and propionic acid in POME were analysed and presented in the amount of 0.6, 0.1 and $0.07 \mathrm{~g}_{\text {litre }}{ }^{-1}$, respectively. However, POME was pre-treated by centrifugation and diluted to $25 \%$. From our preliminary studies it was found that C. acetobutylicum was able to grow in POME without sludge and produced nearly $0.8 \mathrm{~g}$ litre $^{-1} \mathrm{ABE}$ after 72 $\mathrm{hr}$ of cultivation. In addition, it was also found that POME at 25\% concentration gave better results (data not shown). The centrifugation of POME before cultivation was necessary due to the presence of sludge inhibited bacterial cell growth (Sangkharak and Prasertsan, 2012). The dilution of POME helps

TABLE 2. BIOCHEMICAL COMPOSITIONS OF OIL PALM WASTES BEFORE AND AFTER STEAM EXPLOSION TREATMENT

\begin{tabular}{lcccccccc}
\hline \multirow{2}{*}{ Samples } & \multicolumn{2}{c}{ Cellulose (\%) } & & \multicolumn{2}{c}{ Hemicellulose (\%) } & & \multicolumn{2}{c}{ Lignin (\%) } \\
\cline { 2 - 3 } & Before & After & & Before & After & & Before & After \\
\hline $\begin{array}{l}\text { Empty fruit } \\
\text { bunch (EFB) }\end{array}$ & 48.4 & 66.2 & & 38.3 & 40.6 & & 22.1 & 2.0 \\
$\begin{array}{l}\text { Palm pressed } \\
\text { fibre (PPF) }\end{array}$ & 32.2 & 50.8 & 23.8 & 38.8 & & 17.2 & 10.4 \\
$\begin{array}{l}\text { Palm kernel shell } \\
\text { (PKS) }\end{array}$ & 10.4 & 12.5 & & 20.8 & 22.3 & & 50.7 & 48.1 \\
\hline
\end{tabular}


to reduce oil and soluble toxic substances leaving less inhibitory POME which is more suitable for growth of Clostridia (Kalil et al., 2003).

The ABE production from 25\% POME supplemented with EFB was compared to the production from diluted POME and TYA medium alone. However, the production of $\mathrm{ABE}$ from diluted POME and TYA medium were very low ABE (1.1$\left.1.7 \mathrm{~g} \mathrm{litre}^{-1}\right)$. It could be due to the unavailability of sugars for Clostridium to further convert acids to ABE (Ponthein and Cheirsilp, 2011). It was obvious that the $\mathrm{ABE}$ was mostly produced from glucose. The supplement of organic acid and glucose was found to enhance yield of butanol and the conversion of acids to ABE, respectively. While, the fermentation of diluted POME or TYA medium supplemented with pre-treated EFB, PPF and PKS yielded higher ABE. The production of $\mathrm{ABE}$ and butanol using different oil palm waste in this study were also compared with the results published by previous published articles (Table 3). In comparison to previously report, the production of butanol and $\mathrm{ABE}$ by $C$. acetobutylicum has shown a considerable increase using oil palm waste indicating the high ability of $C$. acetobutylicum for $\mathrm{ABE}$ production by consuming a variety of oil palm waste as substrate. However, low butanol yield and $\mathrm{ABE}$ production was obtained when compared with other lignocellulosic compounds due to the high concentration of hemicelluloses component in oil palm waste which hampered the consumption of glucose and mannose by Clostridium sp. (Shukor et al., 2014b).

TABLE 3. THE COMPARISON OF ACETONE, BUTANOL AND ETHANOL (ABE) PRODUCTION FROM VARIOUS LIGNOCELLULOSIC WASTES

\begin{tabular}{|c|c|c|c|c|c|}
\hline Substrate & $\begin{array}{l}\text { Hydrolysis } \\
\text { method }\end{array}$ & Microorganism & $\begin{array}{l}\text { Productivity } \\
\left(\mathrm{g} \mathrm{litre}^{-1} \mathrm{hr}^{-1}\right)\end{array}$ & $\begin{array}{l}\text { Total ABE } \\
\left(\mathrm{g} \text { litre }^{-1}\right)\end{array}$ & Reference \\
\hline Wheat straw & $\mathrm{H}_{2} \mathrm{SO}_{4}+$ enzyme & Clostridium beijerinckii $\mathrm{P} 260$ & 0.42 & 25 & Qureshi et al. ( 2007) \\
\hline Corn fibre & $\mathrm{H}_{2} \mathrm{SO}_{4}$ & C. beijerinckii BA101 & 0.10 & 9.3 & Qureshi et al. (2008) \\
\hline $\begin{array}{l}\text { Dried distillers' grains and } \\
\text { soluble (DDGS) }\end{array}$ & $\begin{array}{l}\text { Ammonium } \\
\text { fibre expansion+ } \\
\text { enzyme }\end{array}$ & C. beijerinckii BA101 & 0.14 & 10.4 & Ezeji and Blaschek (2008) \\
\hline $\begin{array}{l}\text { Rice bran }+ \text { defatted rice } \\
\text { bran }\end{array}$ & $\mathrm{HCl}+$ enzyme & C. beijerinckii NCIMB 8052 & 0.26 & 16.42 & Lee et al. (2009) \\
\hline Barley straw & $\mathrm{H}_{2} \mathrm{SO}_{4}+$ enzyme & C. beijerinckii P260 & 0.39 & 26.64 & Qureshi et al. (2010a) \\
\hline Corn stover & $\mathrm{H}_{2} \mathrm{SO}_{4}+$ enzyme & C. beijerinckii P260 & 0.31 & 26.27 & Qureshi et al. (2010b) \\
\hline Switchgrass & & & 0.17 & 14.61 & \\
\hline Wheat bran & $\mathrm{H}_{2} \mathrm{SO}_{4}$ & C. beijerinckii ATCC 55025 & 0.16 & 11.8 & Liu et al. (2010) \\
\hline Sugar maple wood & $\begin{array}{l}\text { Hot water } \\
\text { extraction }+\mathrm{H}_{2} \mathrm{SO}_{4}\end{array}$ & C. acetobutylicum ATCC 824 & 0.15 & 11.0 & Sun and Liu (2011) \\
\hline Rice straw & $\mathrm{H}_{2} \mathrm{SO}_{4}+$ enzyme & C. acetobutylicum MTCC 481 & 0.017 & 3.0 & Ranjan and Moholkar (2011) \\
\hline Cassava bagasse & Enzyme & C. acetobutylicum JB 200 & 0.62 & 33.87 & Lu et al. (2012) \\
\hline Maize stalk juice & NA & C.beijerinckii NCIMB 8052 & 0.30 & 11.5 & Wang and Blaschek (2011) \\
\hline Dried date fruit & No treatment & C. acetobutylicum NCIMB 13557 & 0.16 & 11.0 & Khamaiseh et al. (2014) \\
\hline Empty fruit bunch (EFB) & Enzyme & C. acetobutylicum & 0.004 & 1.262 & Noomtim and Cheirsilp (2011) \\
\hline $\begin{array}{l}30 \% \text { Palm kernel cake } \\
(\mathrm{PKC})\end{array}$ & No treatment & C. saccharoperbutylacetonicum N1-4 & 0.003 & 0.579 & Shukor et al. (2014a) \\
\hline PKC & Acid hydrolysis & C. saccharoperbutylacetonicum N1-4 & 0.02 & 3.59 & Shukor et al. (2014b) \\
\hline $\begin{array}{l}\text { Palm oil mill effluent } \\
\text { (POME) }\end{array}$ & No treatment & C. saccharoperbutylacetonicum N1-4 & 0.007 & 2.09 & Al-Shorgani et al. (2015) \\
\hline POME+sago starch & Enzyme & C. saccharoperbutylacetonicum N1-4 & 0.10 & 14.38 & Hipolito et al. ( 2008) \\
\hline Diluted POME & Steam explosion & C. acetobutylicum TISTR1462 & 0.02 & 1.7 & This study \\
\hline EFB+TYA medium & - & - & 0.05 & 4.1 & - \\
\hline $\begin{array}{l}\text { Palm pressed fibre } \\
\text { (PPF)+TYA medium }\end{array}$ & - & - & 0.04 & 3.3 & - \\
\hline $\begin{array}{l}\text { Palm pressed fibre } \\
(\mathrm{PPF})+\text { TYA medium }\end{array}$ & - & - & 0.02 & 1.6 & - \\
\hline Diluted POME+EFB & - & - & 0.05 & 3.8 & - \\
\hline Diluted POME+EFB & - & - & 0.04 & 3.2 & - \\
\hline Diluted POME+EFB & - & - & 0.01 & 1.1 & - \\
\hline
\end{tabular}

Note: ABE - acetone-butanol-ethanol. NA - not available. TYA - tryptone-yeast extract actate. 
Time Course of Acetone-butanol-ethanol Production from C. acetobutyricum Using Diluted Palm Oil Mill Effluent Supplemented with Pre-treated Palm Oil Empty Fruit Bunch as Substrate

Time course on growth and ABE production by C. acetobutyricum in diluted POME and pre-treated EFB as carbon sources for $144 \mathrm{hr}$ incubation on a shaker $(60 \mathrm{rpm})$ at $37^{\circ} \mathrm{C}$ was obtained (Figure 2). During cultivation, the $\mathrm{pH}$ decreased to a slightly acidic $\mathrm{pH}$ (from 7.0 to 5.5) due to the acid production (acetic acid and butyric acid). Maximum growth was obtained after $72 \mathrm{hr}$ cultivation whereas ABE production showed the same potential as cellular growth. The maximum ABE was $3.8 \mathrm{~g}$ litre $^{-1}(0.1 \mathrm{~g}$ litre $^{-1}$ acetone, $3.5 \mathrm{~g}_{\text {litre }} \mathrm{e}^{-1}$ butanol and $0.2 \mathrm{~g} \mathrm{litre}^{-1}$ ethanol) and $2.0 \mathrm{~g}$ litre $^{-1}$ total acids ( $0.8 \mathrm{~g}$ litre $^{-1}$ acetic acid and $1.2 \mathrm{~g}$ litre $^{-1}$ butyric acid).

The Production of Polyhydroxyalkanoate from Wastewater after Acetone-butanol-ethanol Production

After ABE production was recovered by the distillation method, the wastewater was collected and characterised. Low nitrogen content and ammonium-nitrogen at 460 ppm and 130 ppm in supernatant were observed, respectively. The BOD, COD and oil content decreased after ABE fermentation process (Table 4). The $\mathrm{pH}$ was acidic ( $\mathrm{pH} 5.5)$ due to the present of organic acid profiles such as acetic acid, particularly propionic and butyric acid in supernatant at the amount of 0.1-1.0 g litre ${ }^{-1}$. Higher amount of organic acid detected in supernatant indicated the conversion of organic acid from nutrients in the substrate. In addition, acetic and butyric present in supernatant are possibly used for PHA production.

The production of PHB was firstly evaluated in different medium (Table 5). The major components in the medium are sugars and the organic acids. The quantity of sugar was range from 2.09 to 18.01 $\mathrm{g} \mathrm{litre}^{-1}$ depending on the substrate. Fermentation using $C$. necator resulted in the PHB concentration of around $0.80-3.24 \mathrm{~g} \mathrm{litre}^{-1}$ with a PHB content of $31.02 \%-48.40 \%$ of DCW. The amount of biomass and PHB generated was strongly correlated with the initial amount of sugar. The PHB production was better in medium with higher initial sugar concentration. The highest PHB content (48.40\%)
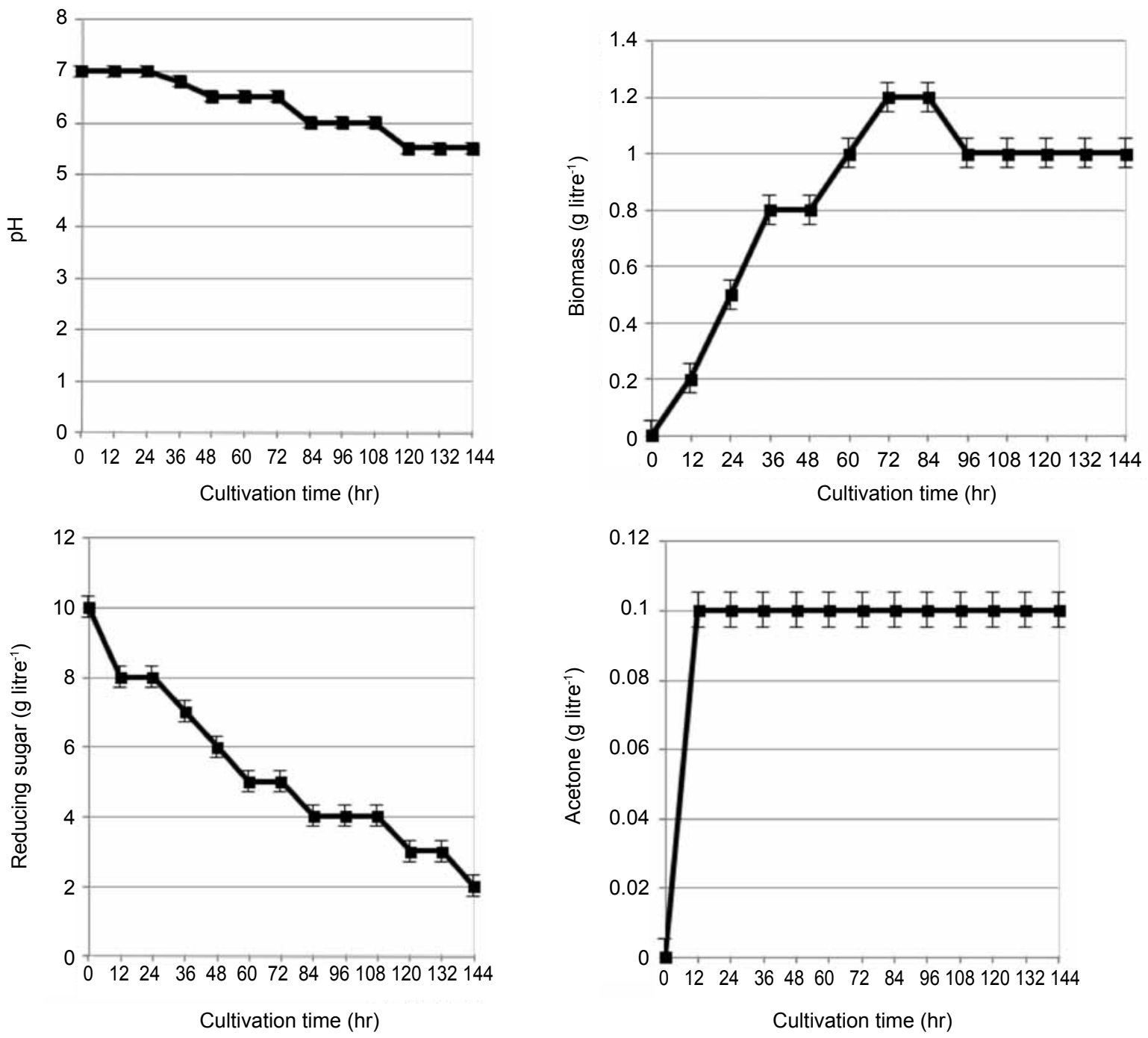

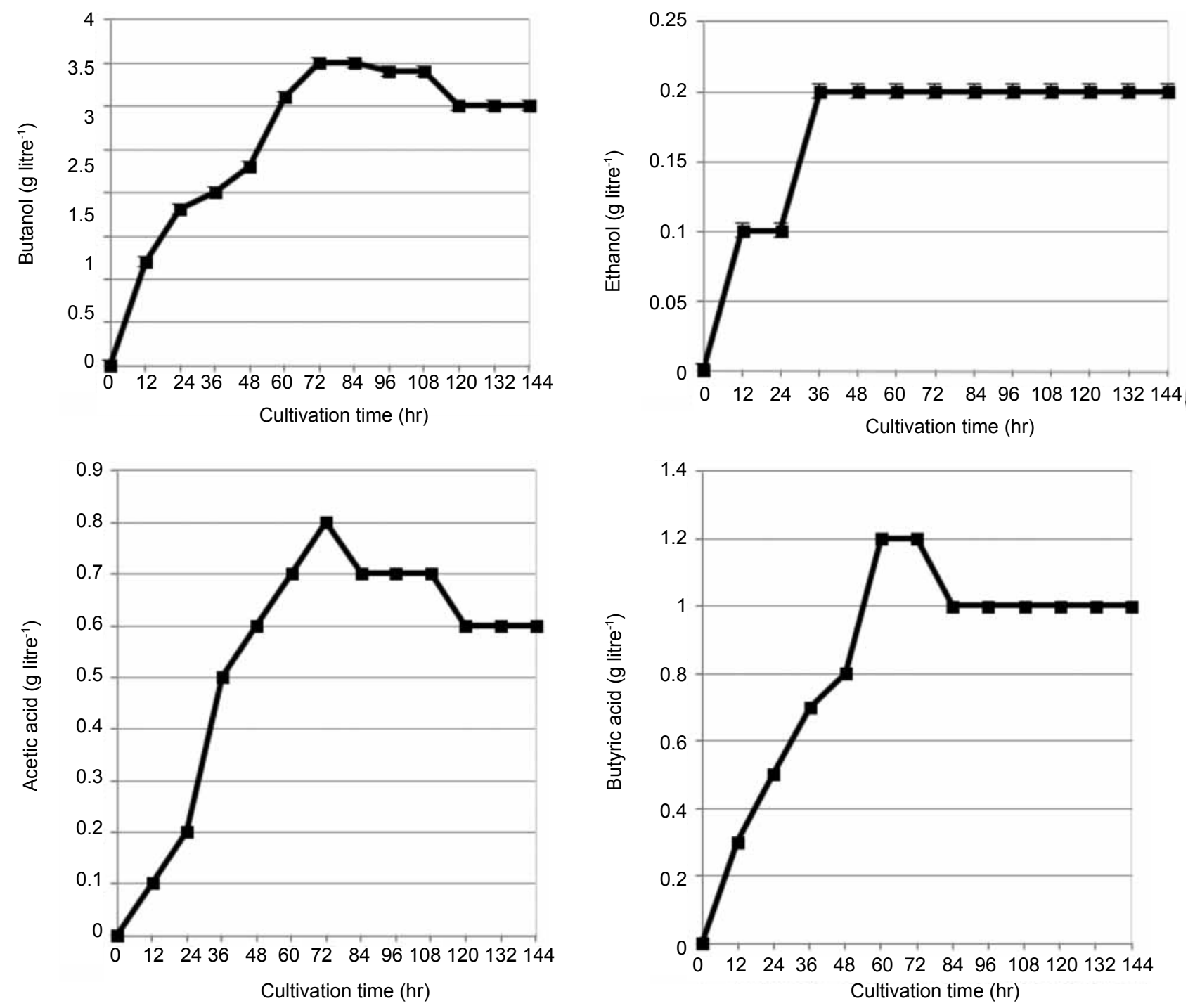

Figure 2. Time course of acetone-butanol-ethanol production from $\mathrm{C}$. acetobutyricum using diluted palm oil mill effluent supplemented with pre-treated palm oil empty fruit bunch as substrate.

TABLE 4. CHARACTERISTICS OF PALM OIL MILL EFFLUENT (POME) BEFORE ACETONE-BUTANOL-ETHANOL (ABE) FERMENTATION AND WASTEWATER AFTER ABE RECOVERY

\begin{tabular}{lcrc}
\hline \multicolumn{1}{c}{ Compositions } & Unit & POME & $\begin{array}{c}\text { Wastewater after ABE } \\
\text { recovery (\% reduction) }\end{array}$ \\
\hline Total nitrogen & $\mathrm{ppm}$ & 850 & $460(45.88 \%)$ \\
Ammonium-nitrogen & $\mathrm{ppm}$ & 150 & $130(13.33 \%)$ \\
Biochemical oxygen demand & $\mathrm{ppm}$ & 20000 & $15000(25 \%)$ \\
Chemical oxygen demand & $\mathrm{ppm}$ & 80500 & $75000(6.83 \%)$ \\
Total solids & $\mathrm{mg} \mathrm{litre}{ }^{-1}$ & 46060 & $38800(15.76 \%)$ \\
Suspended solids & $\mathrm{mg} \mathrm{litre}{ }^{-1}$ & 8354 & $6514(22.02 \%)$ \\
Oil & - & 10000 & $4500(55 \%)$ \\
pH & $\mathrm{mg} \mathrm{litre}{ }^{-1}$ & 4.59 & 5.50 \\
Temperature & ${ }^{\circ} \mathrm{C}$ & 70 & 37 \\
Colour & - & $B r o w n$ & Brown \\
Acetic acid & $\mathrm{g} \mathrm{litre} \mathrm{e}^{-1}$ & 0.1 & 0.8 \\
Propionic acid & $\mathrm{g}$ litre & \\
Butyric acid & $\mathrm{g}$ litre & 0.07 & 0.1 \\
& & 0 & 1.0 \\
\hline
\end{tabular}


TABLE 5. THE PRODUCTION OF POLYHYDROXYBUTYRATE (PHB) UNDER DIFFERENT CULTIVATION MEDIUM AFTER ACETONE-BUTANOL-ETHANOL (ABE) RECOVERY AT $60 \mathrm{hr}$ OF CULTIVATION

\begin{tabular}{|c|c|c|c|c|c|}
\hline \multirow{2}{*}{$\begin{array}{l}\text { Conditions } \\
\text { number }\end{array}$} & \multirow{2}{*}{$\begin{array}{l}\text { Medium after } A B E \\
\text { recovery }\end{array}$} & \multirow{2}{*}{$\begin{array}{l}\text { Initial sugar } \\
\quad\left(\mathrm{g} \text { litre }^{-1}\right)\end{array}$} & \multirow{2}{*}{$\begin{array}{l}\text { Biomass } \\
\left(\mathrm{g} \mathrm{litre}^{-1}\right)\end{array}$} & \multicolumn{2}{|c|}{ PHB production } \\
\hline & & & & $\begin{array}{l}\text { Concentration } \\
\left(\mathrm{g} \mathrm{litre}^{-1}\right)\end{array}$ & $\begin{array}{l}\text { Content } \\
(\%)\end{array}$ \\
\hline 1 & $180 \mathrm{ml}$ diluted POME & $2.09 \pm 0.25$ & $2.58 \pm 0.41$ & $0.80 \pm 0.09$ & 31.02 \\
\hline 2 & $\begin{array}{l}180 \mathrm{ml} \text { TYA medium + } \\
10 \mathrm{~g} \text { pre-treated EFB }\end{array}$ & $18.01 \pm 1.01$ & $6.72 \pm 0.52$ & $3.24 \pm 0.14$ & 48.25 \\
\hline 3 & $\begin{array}{l}180 \mathrm{ml} \text { TYA medium + } \\
10 \mathrm{~g} \text { pre-treated PPF }\end{array}$ & $10.12 \pm 1.20$ & $6.78 \pm 0.51$ & $3.01 \pm 0.20$ & 44.42 \\
\hline 4 & $\begin{array}{l}180 \mathrm{ml} \text { TYA medium + } \\
10 \mathrm{~g} \text { pre-treated PKS }\end{array}$ & $3.45 \pm 0.51$ & $6.41 \pm 0.47$ & $2.58 \pm 0.21$ & 40.23 \\
\hline 5 & $\begin{array}{c}180 \mathrm{ml} \text { diluted POME + } \\
10 \mathrm{~g} \text { pre-treated EFB }\end{array}$ & $18.00 \pm 1.25$ & $6.44 \pm 0.25$ & $3.12 \pm 0.20$ & 48.40 \\
\hline 6 & $\begin{array}{c}180 \mathrm{ml} \text { diluted POME + } \\
10 \mathrm{~g} \text { pre-treated PPF }\end{array}$ & $8.45 \pm 1.24$ & $6.24 \pm 0.50$ & $2.75 \pm 0.19$ & 44.10 \\
\hline 7 & $\begin{array}{c}180 \mathrm{ml} \text { diluted POME + } \\
10 \mathrm{~g} \text { pre-treated PKS }\end{array}$ & $2.24 \pm 0.28$ & $2.67 \pm 0.40$ & $0.91 \pm 0.05$ & 34.14 \\
\hline
\end{tabular}

Note: TYA - tryptone-yeast extract- acetate. POME - palm oil mill effluent. PKS - palm kernel shell. PPF - palm pressed fibre. EFB - empty fruit bunch.

was observed in the medium with POME and pretreated EFB. Therefore, the optimum medium was selected and scaled up into 3 litres fermentor.

The maximum PHB accumulation in C. necator was reported to occur between $48-72 \mathrm{hr}$ of incubation (Sangkharak and Prasertsan, 2011). Hence, C. necator cells grown in supernatant were harvested between 0-96 hr incubation. During cultivation, the $\mathrm{pH}$ increased to a slightly alkali $\mathrm{pH}$ (from 5.5 to 8.02 ) due to the depletion of carbon source and the generation of ammonia from nitrogen source consumption. Maximum growth was obtained after $60 \mathrm{hr}$ cultivation whereas PHB concentration and PHB content showed the same potential as cellular growth. The maximum PHB in the cells was $48.4 \%$ of DCW and gave the PHB concentration of about $3.12 \pm 0.24 \mathrm{~g}$ litre $^{-1}$ (Figure 3). Wastewater from ABE fermentation by $C$. beijerinckii NRRL B592 has been determined for PHA production by Parrer et al. (2000). After evaporation process, $7 \mathrm{~g}$ litre $^{-1}$ of butyrate and $5 \mathrm{~g}$ litre $^{-1}$ of acetate at $\mathrm{pH} 7.5$ was added to the medium. The bacterium identified as a representative of the genus Alcaligenes (designated as Alcaligenes sp. $\mathrm{G})$ was capable of growth up to optical densities

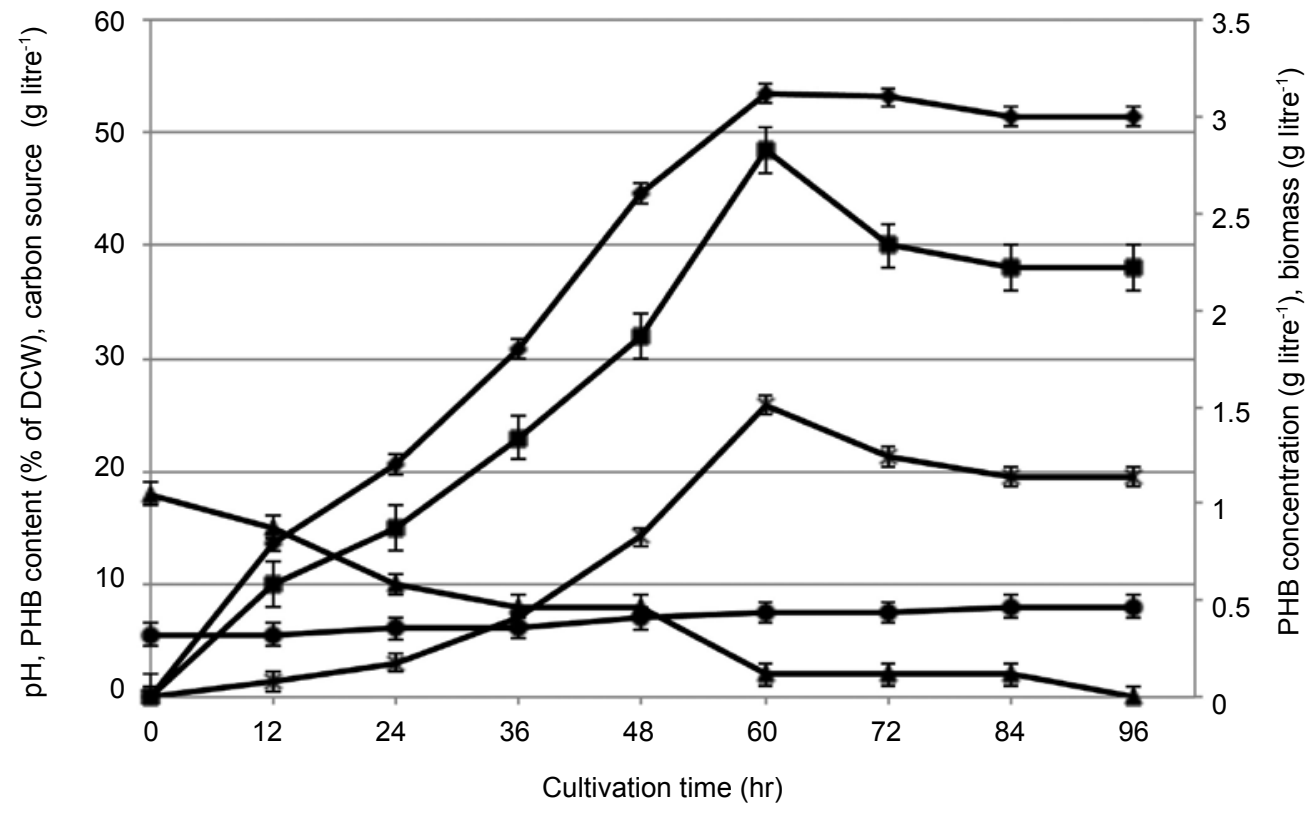

Figure 3. Time course of $p H(\bullet)$, biomass $\left(g\right.$ litre $\left.{ }^{-1}, \bullet\right)$, polyhydroxybutyrate $(P H B)$ concentration $\left(g\right.$ litre $\left.{ }^{-1},{ }^{*}\right)$, PHB content $[\%$ of dry cell weight $(D C W), \mathbf{\square}$ and carbon source $\left(g\right.$ litre $\left.^{-1}, \mathbf{\Delta}\right)$ from wastewater after acetone-butanol-ethanol $(A B E)$ production. 
ranging from 8 to 20 and simultaneously of PHAaccumulation up to $40 \%$ of DCW. In comparison to previously report, the production of PHA by C. necator has shown a considerable increase using $\mathrm{ABE}$ wastewater indicating the high ability of $C$. necator for PHA production by consuming $\mathrm{ABE}$ wastewater as substrate.

To specifically determine the composition of the isolated polymer, the freeze dried cell material and the commercial PHB were subjected to esterification. The propyl esters formed were analysed by GC and benzoic acid propyl ester was used as the internal standard. The peak corresponding to propyl ester of 3-hydroxybutyric acid was observed in the gas chromatogram (retention time $8.5 \mathrm{~min}$ ) for PHB from $C$. necator. This indicated that the polymer accumulated by $C$. necator was PHB. The structure of PHB was confirmed by ATR-FTIR compared with commercial PHB. The ATR-FTIR spectra for PHB samples extracted from C. necator after $60 \mathrm{hr}$ of cultivation was compared with the spectrum obtained from commercial PHB (Figure 4). The FTIR spectra obtained for extracted PHB presented almost identical peak positioning when compared to the spectrum obtained from commercial PHB. The most prominent marker band for the identification of PHB is the ester carbonyl band at $1700-1725 \mathrm{~cm}^{-1}$. The bands present at $1178 \mathrm{~cm}^{-1}, 1228 \mathrm{~cm}^{-1}$ and 1263 $\mathrm{cm}^{-1}$ are bands sensitive to crystallinity and are characteristic of C-O-C. The spectra were found to be identical, which confirms the extracted polymer as PHB.

\section{CONCLUSION}

The maximum ABE was $3.8 \mathrm{~g}$ litre $^{-1}$ and $2.0 \mathrm{~g} \mathrm{litre}^{-1}$ total acids was obtained from the cultivation of C. acetobutyricum under $180 \mathrm{ml}$ of diluted POME with $10 \mathrm{~g}$ litre $\mathrm{e}^{-1}$ of pre-treated. The supernatant after ABE removal was collected for PHB production. The maximum PHB in the cells was $48.4 \%$ of DCW and gave the PHB concentration of about $3.12 \pm 0.24$ $\mathrm{g}$ litre $^{-1}$ after $60 \mathrm{hr}$ of cultivation. During processing in the palm oil mill more than $70 \%$ (by weight) of the processed biomass were left over as oil palm waste. Therefore, utilisation of palm wastes for ABE and PHB fermentation as described in this study showed the great possibility to reduce wastes from palm oil process. However, the development of simply process using less chemical and technology will be the next experiment to make this method appears to be a realistic goal for the future.

\section{ACKNOWLEDGEMENT}

The authors would like to thank the Research and Development Institute, Thaksin University as well as Thailand Research Fund (TRF) Grant for New Researcher (project number MRG 5680050 and RTA5780002) for their financial support. Finally, I would like to thank Dr Christopher Joseph Forti (English adviser and English proof-reader, Thaksin University) for useful comments and suggestions on the language and structure of our manuscript.

\section{REFERENCES}

AL-SHORGANI, N K N; KALIL, M S and WAN YUSOFF, W M (2012). Fermentation of sago starch to biobutanol in a batch culture using Clostridium saccharoperbutylacetonicum N1-4 (ATCC 13564). Ann. Microbio., 62: 1059-1070. DOI:10.1007/s13213-0110347-x.

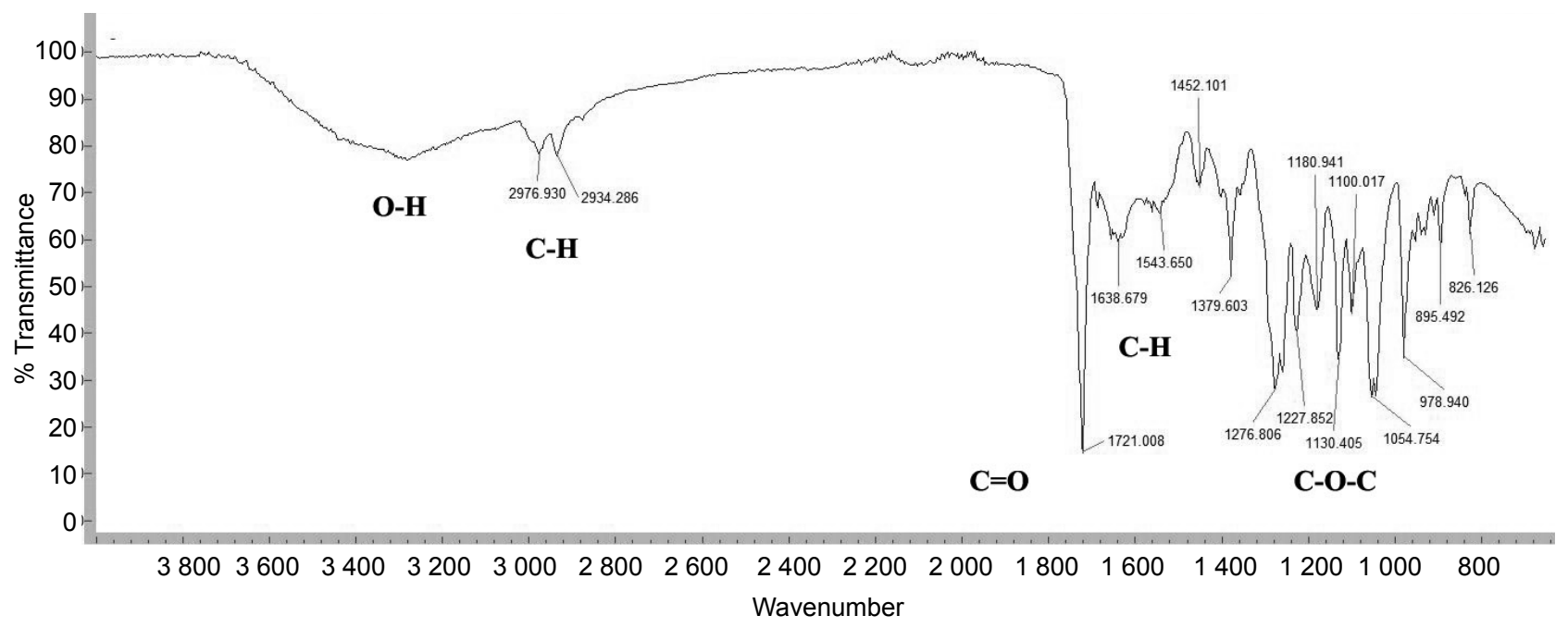

Figure 4. Attenuated total reflectance-Fourier transform infrared spectroscopy (ATR-FTIR) spectra of polyhydroxybutyrate (PHB) extracted from C. necator after $96 \mathrm{hr}$ of cultivation. 
AL-SHORGANI, N $\mathrm{K} \quad \mathrm{N}$; SHUKOR, $\mathrm{H}$; ABDESHAHIAN, P; NAZIR, M Y M; KALIL, M S; HAMID, A A and YUSOFF, W W M (2015). Process optimization of butanol production by Clostridium saccharoperbutylacetonicum N1-4 (ATCC 13564) using palm oil mill effluent in acetone-butanol-ethanol fermentation. Biocatal. Agric. Biotechnol., 4: 244-249. DOI: 10.1016/j.bcab.2015.02.004.

AMERICAN PUBLIC HEALTH ASSOCIATION (APHA) (1998). Standard Methods for the Examination of Water and Wastewater. 20 ${ }^{\text {th }}$ ed. APHA, Washington, DC. DOI: 10.2105/ AJPH.51.6.940-a.

AOAC (1990). Official Method of Analysis of the Association of Analytical Chemists. $14^{\text {th }}$ ed. The Association of Official Analytical Chemists. Miller. USA. DOI: 10.1016/S0003-2670(00)86185-1.

CHAVALPARIT, O; RULKENS, W H; MOL, A P J and KHAODHAIR, S (2006). Options for environmental sustainability of the crude palm oil industry in Thailand through enhancement of industrial ecosystems. Environ. Dev. Sustain., 8: 271287. DOI:10.1007/s10668-014-9588-8.

EZEJI, T C and BLASCHEK, HP(2008). Fermentation of dried distillers' grains and soluble (DDGS) hydrolysates to solvents and value-added products by solventogenic clostridia. Bioresour. Technol., 99: 5232-5242. DOI: 10.1016/j.biortech.2007.09.032.

HIPOLITO, C N; CRABBE, E; BADILLO, C M; ZARRABAL, O C; MORA, M A M; FLORES, G P; CORTAZAR, M de A H and ISHIZAKI, A (2008). Bioconversion of industrial wastewater from palm oil processing to butanol by Clostridium saccharoperbutylacetonicum N1-4 (ATCC 13564). J. Cleaner Prod., 16: 632-638. DOI: 10.1016/j. clepro.2007.02.005.

IBRAHIM, M F; ABD-AZIZ, S; RAZAK, M N A; PHANG, L Y and HASSAN, M A (2012). Oil palm empty fruit bunch as alternative substrate for acetone-butanol-ethanol production by Clostidrium butyricum EB6. Appl. Biochem. Biotechnol., 35: 10551059. DOI: $10.1007 /$ s12010-012-9538-6.

IBRAHIM, M F; ABD-AZIZ, S; YUSOFF, M E M; PHANG, L Y and HASSAN, M A (2015). Simultaneous enzymatic saccharification and ABE fermentation using pretreated oil palm empty fruit bunch as substrate to produce butanol and hydrogen as biofuel. Renew. Energ., 77: 447-455. DOI: 10.1016/j. renene.2014.12.047.

JONES, D T and WOODS, D R (1986). Acetonebutanol fermentation revisited. Microbiol. Rev., 50: 484-524. DOI: 0146-0749/86/040484-41\$02.00/0.

KALIL, M S; KIT, P W; YUSOFF W M W; SADAZO, $Y$ and RAHMAN, R A (2003). Direct fermentation of palm oil mill effluent to acetone-butanol-ethanol by solvent producing Clostridia. Pak. J. Biol. Sci., 6: 12731275. DOI: $10.3923 /$ pjbs.2003.1273.1275.

KHAMAISEH, E I; ABDUL HAMID, A; ABDESHAHIAN, P; YUSOFF, W W $\mathrm{M}$ and KALIL, M S (2014). Enhanced butanol production by Clostridium acetobutylicum NCIMB 13357 grown on date fruit as carbon source in P2 medium. Sci. World. J., DOI: $10.1155 / 2014 / 395754$.

LEE, S Y; PARK, J H; JANG, S H; NIELSEN, S K; KIM, J and JUNG, K S (2008). Fermentative butanol production by Clostridia. Biotechnol. Bioeng., 101: 210224. DOI: $10.1002 /$ bit.22003.

LEE, J; SEO, E; KWEON, D H; PARK, K and JIN, Y S (2009). Fermentation of rice bran and defatted rice bran for butanol production using Clostridium beijerinckii NCIMB 8052. J. Microbiol. Biotechnol., 19: 482-490. DOI: 10.1014/jmb.0804.275.

LIU, X and YANG, S T (2006). Kinetics of butyric acid fermentation of glucose and xylose by Clostridium tyrobutyricum wild type and mutant. Process Biochem., 41: 801-808. DOI: 10.1016/j.procbio.2005.10.009.

LIU, Z; YING, Y; LI, F; MA, C and XU P (2010). Butanol production by Clostridium beijerinckii ATCC 55025 from wheat bran. J. Ind. Microbiol. Biotechnol., 37(5): 495-501. DOI: 10.1007/s10295-010-0695-8.

LU, C; ZHAO, J; YANG, S T and WEI, D (2012). Fed-batch fermentation for n-butanol production from cassava bagasse hydrolysate in a fibrous bed bioreactor with continuous gas stripping. Bioresour. Technol., 104: 380-387. DOI:10.1016/j. biortech.2011.10.089.

MAKKAR, R S; CAMEOTRA, S S and BANAT, I $M$ (2011). Advanced in utilization of renewable substrates for biosurfactant production. $A M B$ Express, 1: 5. DOI: 10.1186/2191-0855-1-5.

MILLER, G L (1959). Use of dinitrosalicylic acid reagent for determination of reducing sugar. Anal. Chem., 31: 426-428. DOI: 10.1021 / ac60147a030.

MITCHELL, W T (1998). Physiological of carbohydrate to solvent conversion by Clostridia. Adv. Microb. Physiol., 39: 31-130. DOI: 10.1016/S00652911(08)60015-6.

MUN, L T; ISHIZAKI, A; YOSHINO, $\mathrm{S}$ and FURUKAWA, K (1995). Production of acetone, butanol and ethanol from palm oil waste by Clostridium saccharoperbutylacetonicum N14. Biotechnol. Lett., 17: 649-654. DOI: 10.1007/ BF00129394.

NOOMTIM, Pand CHEIRSILP,B(2011). Production of butanol from palm empty fruit bunches hydrolyzate 
by Clostridium acetobutylicum. Energy Procedia, 9: 140146. DOI: 10.1016/j.egypro.2011.09.015.

OLIVEIRA, F C; DIAS, M L; CASTILHO, L R and FREIRE, D M G (2007). Characterization of poly(3hydroxybutyrate) produced by Cupriavidus necator in solid-state fermentation. Bioresour. Technol., 96: 633-638. DOI: 10.1016/j.biortech.2006.02.022.

PARRER, G; SCHROLL, G; GAPES, J R; LUBITZ, $\mathrm{W}$ and SCHUSTER, K C (2000). Conversion of solvent evaporation residues from the AB-(acetonebutanol) bioprocess into bacterial cells accumulating thermoplastic polyesters. J.Mol. Microbiol. Biotechnol., 2(1): $81-8$.

PONTHEIN, $\quad W$ and CHEIRSILP, B (2011). Development of acetone butanol ethanol (ABE) production from palm pressed fiber by mixed culture of Clostridium sp. and Bacillus sp. Energy Procedia, 9: 459-467. DOI: 10.1016/j.egypro.2011.09.052.

QURESHI, N; SAHA, B C and COTTA, M A (2007). Butanol production from wheat straw hydrolysate using Clostridium beijerinckii. Bioproc. Biosyst. Eng., 30: 419-427. DOI: 10.1007/ s00449-007-0137-9.

QURESHI, N; SAHA, B C; HECTOR, R E; HUGHES, S R and COTTA, M A (2008). Butanol production from wheat straw by simultaneous saccharification and fermentation using Clostridium beijerinckii: part I - batch fermentation. Biomass Bioenerg., 32: 168-175. DOI: 10.1016/j.biombioe.2007.07.004.

QURESHI, N; SAHA, B C; DIEN, B; HECTOR, R E and COTTA, M A (2010a). Production of butanol (a biofuel) from agricultural residues: part I - use of barley straw hydrolysate. Biomass Bioenerg., 34(4): 559-565. DOI: 10.1016/j.biombioe.2009.12.024.

QURESHI, N; SAHA, B C; HECTOR, R E; DIEN, B; HUGHES, S; LIU, S; ITEN, L; BOWMAN, M J; SARATH, G and COTTA, M A (2010b). Production of butanol (a biofuel) from agricultural residues: part II - use of corn stover and switchgrass hydrolysates. Biomass Bioenerg., 34(4): 566-571. DOI: 10.1016/j. biombioe.2009.12.023.

RANJAN, A and MOHOLKAR, V S (2011). Comparative study of various pretreatment techniques for rice straw saccharification for the production of alcoholic biofuels. Fuel, 112: 567-571. DOI:10.1016/j.fuel.2011.03.030.

SANGKHARAK, K and PRASERTSAN, P (2011). Utilization of biodiesel waste as a feedstock for the production of polyhydroxybutyrate by Cupriavidus necator. Afr. J. Biotechnol., 10(77): 17812-17824. DOI: 10.5897 / AJB11.2184.
SANGKHARAK, K and PRASERTSAN, P (2012). Production of polyhydroxyalkanoate from palm oil mill effluent. Proc. of the 2012 International Conference on Sustainable Environmental Technologies (ICSET). 26-27April 2012, Bangkok, Thailand.

SHUKOR, H; AL-SHORGANI, N $\mathrm{K}$ N; ABDESHAHIAN, P; HAMID, A A; ANUAR, N; RAHMAN, NA; ISA, M H M and KALIL, MS (2014a). Biobutanol production from palm kernel cake (PKC) using Clostridium saccharoperbutylacetonicum N1-4 in batch culture fermentation. BioResources, 9: 53255338.

SHUKOR, H; AL-SHORGANI, N $\mathrm{K}$ N; ABDESHAHIAN, P; HAMID, A A; ANUAR, N; RAHMAN, N A and KALIL, M S (2014b). Production of butanol by Clostridium saccharoperbutylacetonicum N1-4 from palm kernel cake in acetone-butanolethanol fermentation using an empirical model. Bioresour. Technol., 170: 565-573. DOI: 10.1016/j. biortech.2014.07.055.

SINGH, A (1995). Microbial production of acetone and butanol. Microbial Pentose Utilization: Current Application in Biotechnology. Elsevier Science, New York, USA.

SUMATHI, S; CHAI, S P and MOHAMED, A $R$ (2008). Utilization of oil palm as a source of renewable energy in Malaysia. Renew. Sust. Energ. Rev., 12: 2404-2421. DOI: 10.1016/j.rser.2007.06.006.

SUN, Z and LIU, S (2011). Production of $n$-butanol from concentrated sugar maple hemicellulosic hydrolysate by Clostridia acetobutylicum ATCC824. Biomass Bioenerg., 39: 39-47. DOI:10.1016/j. biombioe.2010.07.026.

VANDAK, D; ZIGOVA, J; STURDIK, E and SCHLOSSER, S (1997). Evaluation of solvent and $\mathrm{pH}$ for extractive fermentation of butyric acid. Process Biochem., 32: 245-251. DOI: 10.1016/S00329592(96)00084-2.

WANG, Y and BLASCHEK, H P (2011). Optimization of butanol production from tropical maize stalk juice by fermentation with Clostridium beijerinckii NCIMB 8052. Bioresour. Technol., 102: 9985-9990. DOI: 10.1016/j.biortech.2011.08.038.

WOOD, T M and BHAT, K M (1988). Methods for measuring cellulase activities. Methods Enzymol., 160: 87-112. DOI: 10.1016/0076-6879(88)60109-1. 